\title{
Game Edukasi Mitigasi Bencana Gempa Bumi Berbasis Android
}

\author{
Istiqomah $^{1}$ \\ Endah Sudarmilah ${ }^{2}$ \\ Program Studi Informatika, Fakultas Komunikasi dan Informatika, \\ Universitas Muhammadiyah Surakarta, \\ email: ${ }^{1} 1200150076 @$ student.ums.ac.id, ${ }^{2}$ endah.sudarmilah@ums.ac.id
}

\begin{abstract}
Abstrak: Indonesia merupakan kawasan dengan kondisi Tektonik yang cukup aktif di dunia dan merupakan tempat pertemuan 3 lempeng dunia yang menjadikan Indonesia sebagai kawasan yang rawan gempa bumi. Gempa bumi Aceh tahun 2004, Gempa Bumi Jogja tahun 2006 dan Gempa Bumi Padang tahun 2009 merupakan beberapa gempa yang menewaskan ribuan korban jiwa dan menghancurkan banyak bangunan. Gempa bumi merupakan fenomena alam yang tidak dapat kita hindari, banyaknya korban jiwa akibat gempa bumi dikarenakan kurangnya pengetahuan masyarakat terhadap gempa bumi khususnya anak-anak. Maka dari itu dirasa perlu untuk mengajarkan kepada anak-anak tentang siaga bencana di sekolah melalui sebuah game. Tujuan penulis membuat game edukasi mitigasi gempa bumi agar anak - anak lebih mudah mendapat informasi tentang gempa bumi dan mengetahui bagaimana upaya yang tepat untuk meminimalkan resiko akibat gempa bumi. Penulis menggunakan metode SDLC dengan model Waterfall. Hasil dari penelitian ini adalah game edukasi mitigasi bencana gempa bumi, yang dibuat menggunakan Construct 2. Game ini telah diuji menggunakan System Usability Scale (SUS) dan dapat berjalan dengan baik tanpa adanya kendala.
\end{abstract}

Kata Kunci: construct 2, game edukasi, gempa bumi, penyelamatan korban bencana gempa.

\begin{abstract}
Indonesia is an area with Tectonic conditions that is quite active in the world and is a meeting place for 3 world plates that make Indonesia an earthquake-prone region. The Aceh 2004 earthquake, the Jogja earthquake in 2006 and the Padang earthquake in 2009 were a number of earthquakes that killed thousands of lives and destroyed many buildings. Earthquakes are natural phenomena that we cannot avoid, many people are killed by earthquakes because they involve people fighting earthquakes specifically for children. Therefore, it is necessary to talk with children about disaster preparedness in schools through games. The author's goal is to create an earthquake mitigation education game so that children are more easily informed about earthquakes and find out how to improve earthquake disasters. The author uses the SDLC method with the Waterfall model. The results of this study are earthquake disaster mitigation education games, which were made using Construct 2. This game has been published using the System Usability Scale (SUS) and can be run properly without causing interference.
\end{abstract}

Keywords:construct 2, education game, earthquake, rescue of victim of the earthquake.

\section{PENDAHULUAN}

Secara geografis Indonesia terletak di daerah khatulistiwa dengan morfologi yang beragam dari daratan sampai pegunungan tinggi. Keragaman morfologi tersebut dipengaruhi oleh faktor geologi yaitu dengan adanya aktivitas pergerakan lempeng tektonik aktif di sekitar perairan Indonesia diantaranya adalah lempeng Eurasia, Australia dan Dasar Samudera Pasifik. Pergerakan lempeng-lempeng tektonik tersebut menyebabkan terbentuknya jalur gempa bumi, rangkaian gunung api aktif dan patahan-patahan yang berpotensi menjadi sumber gempa [1].

Serangkaian bencana gempa bumi telah melanda negeri, bencana di Aceh, Yogyakarta dan Sumatra Barat mengakibatkan banyak korban jiwa dan kerugian harta benda. Kesiapsiagaan pada dasarnya merupakan semua upaya dan kegiatan yang dilakukan sebelum terjadi bencana alam untuk secara cepat dan efektif merespon 
keadaan atau situasi pada saat bencana dan segera setelah bencana. Upaya ini sangat diperlukan masyarakat untuk mengurangi risiko/dampak bencana alam, termasuk korban jiwa, kerugian harta benda, dan kerusakan lingkungan [2]. Untuk itu perlu adanya Mitigasi Bencana sebagaimana untuk menghadapi kemungkinan bencana yang akan datang.

Saat ini game menjadi salah satu bagian dalam kehidupan masyarakat modern dari anak kecil hingga orang dewasa. Berdasarkan kajian di atas, banyaknya orang yang memainkan game maka pengembangan game (game development) mulai mengarah ke dalam industri game edukasi. Hal ini dimaksudkan selain mendapatkan hiburan dalam bermain game, pemain juga mendapatkan nilai tambah yaitu pengetahuan [3].

Tujuan pembuatan sebuah game antara lain education (mendidik). Game ini akan lebih diutamakan untuk mendukung proses pembelajaran dengan konsep "Bermain sambil belajar". Untuk sebagian anak, kata "Belajar" akan terasa sangat menakutkan, sehingga diharapkan dengan adanya game pendidikan yang menarik ini, anak tidak akan menyadari jika yang dilakukannya itu adalah termasuk belajar dan anak akan menjadi senang dan mau belajar [4].

Saat ini banyak game yang telah dikembangkan pada smartphone. Teknologi smartphone saat ini berkembang pesat, khususnya smartphone berbasis android. Smartphone berbasis android banyak digunakan karena harganya yang terjangkau dan pengembangannya mudah, serta berbasis open source [5].

Construct 2 merupakan sebuah aplikasi yang digunakan untuk membuat game 2 Dimensi berbasis HTML. Fitur-fitur dari construct 2 meliputi powerfull event system yang berfokus pada logika. Game Construct 2 dapat diterbitkan pada platform berbasis web dan platform mobile seperti iOS dan android [6].

\section{METODE}

Metode yang digunakan penulis yaitu menggunakan metode System Development Life Cycle $(S D L C)$ dengan model Waterfall. Tahapantahapan pada model waterfall yaitu Analisis, Desain, Implementasi, Testing dan Maintenance [7]. Diagram model Waterfall SDLC secara rinci terdapat pada gambar 1.

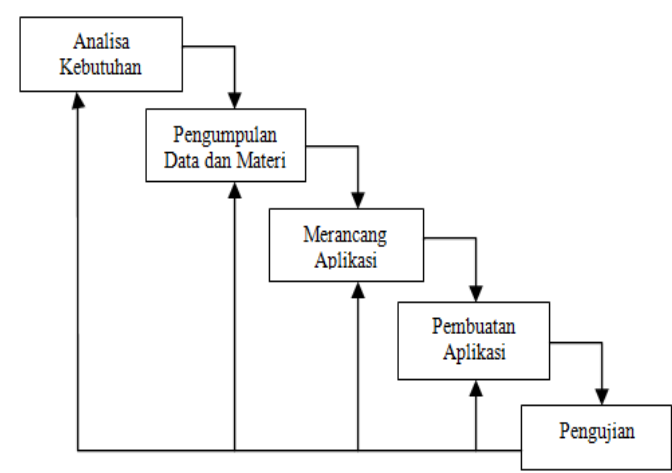

Gambar 1. Diagram Model Waterfall SDLC

Tahapan-tahapan pembuatan aplikasi game edukasi (penjelasan gambar 1) meliputi:

\section{Analisa Kebutuhan}

Dalam pembuatan aplikasi ini dibutuhkan :

\section{Alat dan Bahan}

Tabel 1. Alat dan Bahan

\begin{tabular}{|c|c|c|c|}
\hline \multicolumn{2}{|r|}{ Software } & \multicolumn{2}{|r|}{ Hardware } \\
\hline a) & $\begin{array}{l}\text { Construct } 2 \text { untuk membuat } \\
\text { game }\end{array}$ & a) & $\begin{array}{l}\text { Laptop ASUS } \\
\text { A455L }\end{array}$ \\
\hline b) & $\begin{array}{l}\text { Coreldraw } X 7 \text { untuk } \\
\text { membuat desain objek } 2 D\end{array}$ & $\begin{array}{l}\text { b) } \\
\text { c) }\end{array}$ & $\begin{array}{l}O P P O A 37 \\
R A M 4 G B\end{array}$ \\
\hline c) & $\begin{array}{l}\text { Lexis Audio Editor untuk } \\
\text { mengolah suara }\end{array}$ & & \\
\hline d) & $\begin{array}{l}\text { Phonegap untuk } \\
\text { mengexport game ke format } \\
\text {.apk android }\end{array}$ & & \\
\hline e) & $\begin{array}{l}\text { Windows } 10 \text { sebagai sistem } \\
\text { operasi }\end{array}$ & & \\
\hline
\end{tabular}

\section{Karakter dalam game}

Karakter atau tokoh utama dalam game ini adalah Kuma yang merupakan seorang anak laki - laki yang pemberani dan tangguh dengan ciri khas menggunakan baju berwarna biru.

\section{Pengumpulan Data dan Materi}

Mengumpulkan data yang bersumber dari berbagai macam buku-buku, literatur, referensi dari internet serta pengalaman penulis tentang kebencanaan khususnya gempa bumi.

\section{Perancangan Aplikasi}

\section{Use Case Diagram}

Use case menggambarkan interaksi (dipicu aktor eksternal untuk mencapai tujuan) antara suatu sistem dan lingkungannya [8].

Berdasarkan use case dibawah ini Pemain dapat memulai permainan dengan menekan tombol play, kemudian akan tampil menu pilih level. Kemudian Pemain dat memilih level yang diinginkan. Setelah itu pemain dapat 
memainkan game level 1 sampai 3. Jika pemain kalah maka akan tampil halaman game over sedangkan jika pemain menang maka akan tampil halaman menang. Pemain juga dapat mengatur suara dan keluar dari aplikasi.

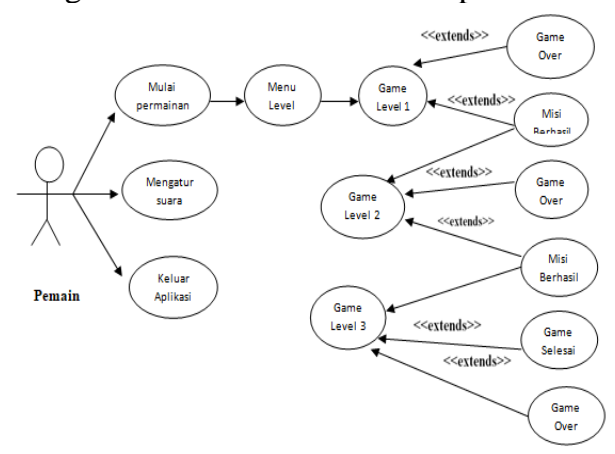

Gambar 2. Use Case Diagram

\section{Activity Diagram}

Diagram Aktivitas merupakan diagram yang memperlihatkan aliran dari suatu aktifitas ke aktifitas lainnya dari suatu sistem [9].

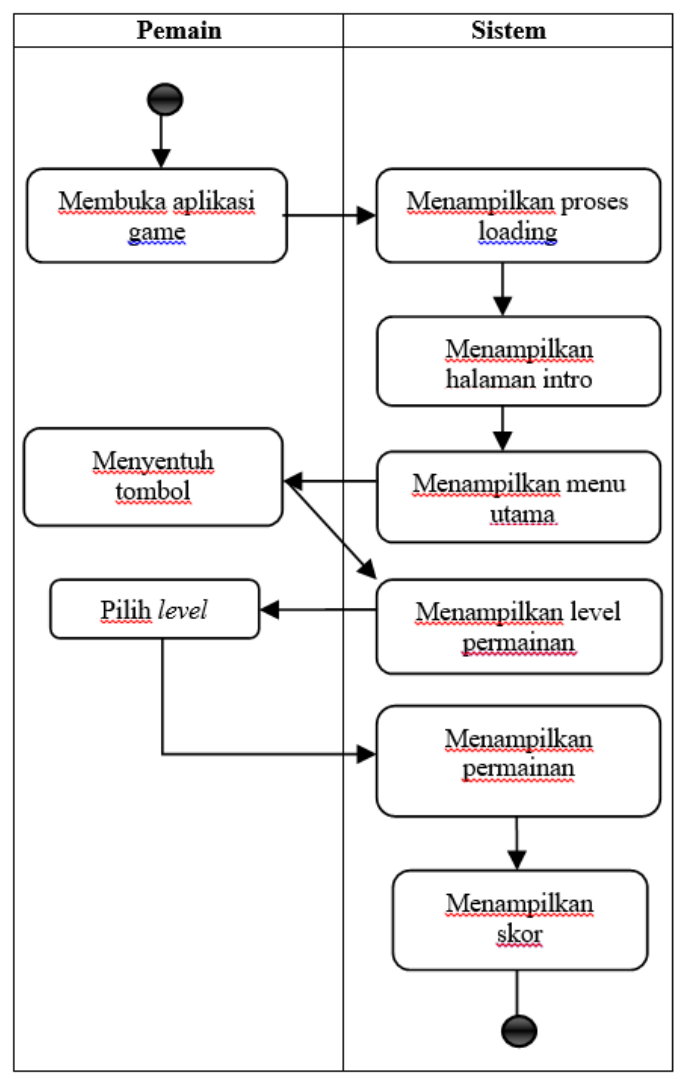

Saat pemain membuka aplikasi game maka sistem akan menampilkan halaman loading, intro dan masuk ke menu utama. Ketika pemain menekan tombol play, sistem akan menampilkan halaman pilih level. Saat pemain memilih level, sistem akan menampilkan permainan. Ketika selesai bermain akan muncul skor serta informasi mengenai gempa bumi.

\section{Storyline}

Game edukasi penyelamatan korban bencana dengan nama game " Run Kuma Run! “ ini bercerita tentang bagaimana seorang anak menyelamatkan diri dari bencana gempa bumi. Game edukasi ini bertujuan untuk memudahkan anak-anak mengetahui mitigasi bencana gempa bumi. Game ini berisi simulasi saat terjadi gempa bumi, materi-materi seperti informasi tentang gempa dan bagaimana cara menyelamatkan diri dan lain-lain. Sasaran dari game ini yaitu anakanak berumur 10-12 tahun. Konsep dari game ini adalah easy, fun dan edukatif. Dalam game edukasi dengan genre adventure ini pemain diminta menyelesaikan misi dan tantangan yang berbeda-beda ditiap levelnya. Pemain dapat mengumpulkan koin dan ketika tokoh karakter berhasil menyelesaikan misi disetiap level maka akan mendapatkan reward berupa informasi tentang gempa bumi dan poin di akhir permainan. Storyboard

Storyboard adalah dokumentasi untuk produksi multimedia interaktif. Didalamnya terdapat pemrograman, skrip audio dan deskripsi rinci elemen visual seperti teks, video, grafik dan animasi [8]. Storyboard dapat dilihat pada tabel 2:

\section{Pembuatan Aplikasi Asset Game}

Asset yang terdapat dalam aplikasi game dibuat sendiri oleh penulis dan mengambil beberapa asset objek dari beberapa sumber seperti kenney.com dan freepik.com. Sementara asset sound diambil dari freesound.org dan bensound.com.

\section{Pengujian}

Pengujian dilakukan setelah penulis selesai membuat game, dengan melakukan pengujian menggunakan uji black box dan pengujian pengguna berupa pengisian kuisioner oleh responden.

Gambar 3. Activity Diagram Memulai Aplikasi 
Tabel 2. Storyboard "Run Kuma Run!"

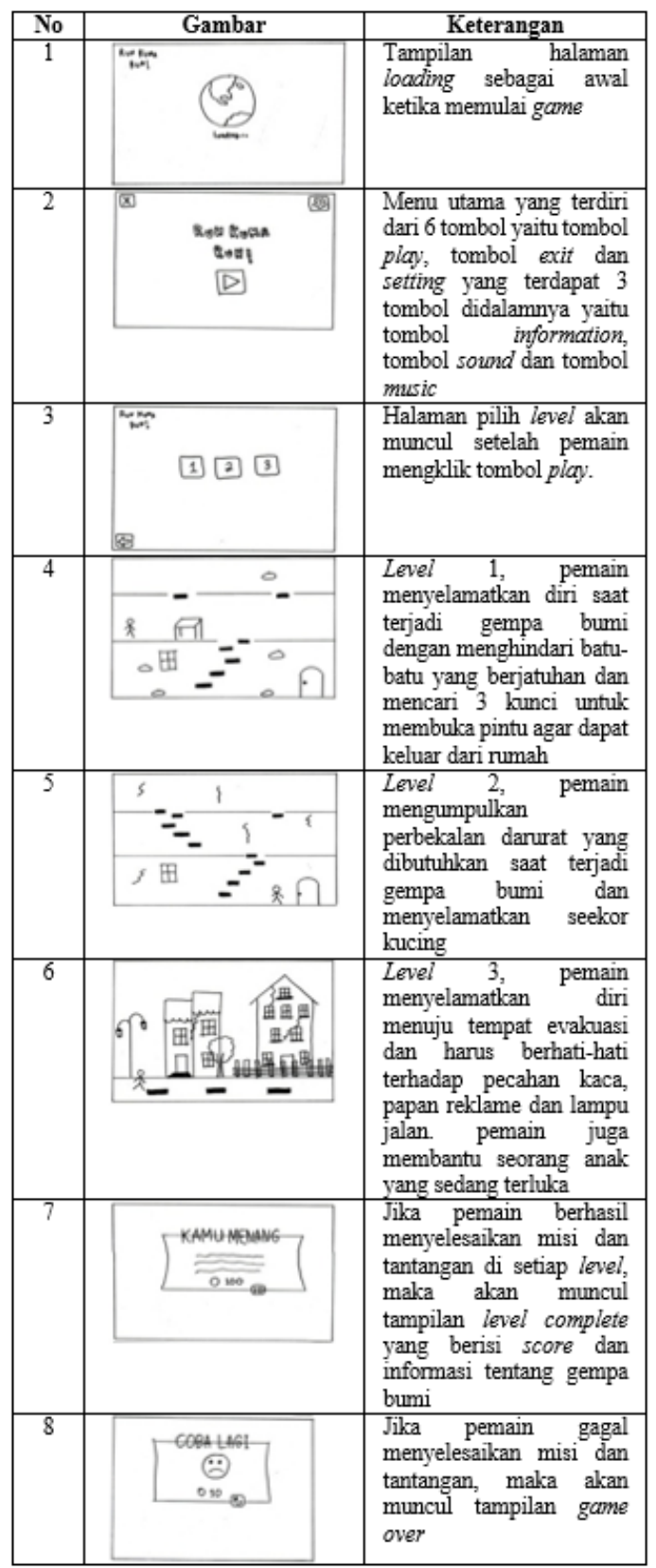

\section{HASIL DAN PEMBAHASAN Hasil Penelitian}

Hasil dari penelitian ini yaitu sebuah game edukasi mitigasi bencana gempa bumi sebagai media pembelajaran yang memberikan informasi tentang gempa bumi. Game ini dapat berjalan dengan ekstensi .apk untuk mobile (berbasis android).

\section{Halaman Awal Game Edukasi}

Halaman awal terdiri dari tampilan loading yang merupakan awalan ketika memulai aplikasi. Halaman loading dan menu utama dapat dilihat pada gambar 4 dan 5 .

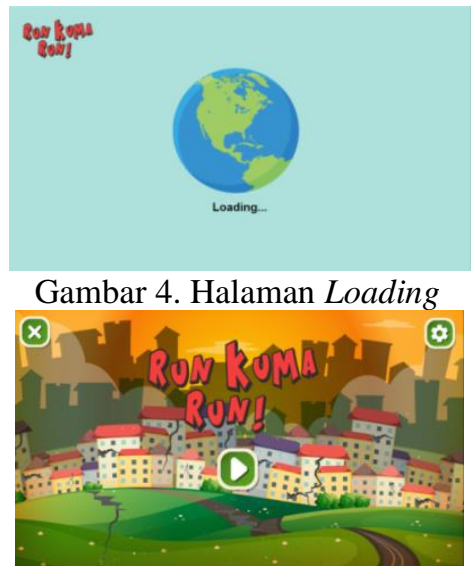

Gambar 5. Halaman Menu Utama

Halaman menu utama memiliki beberapa tombol diantaranya yaitu tombol play untuk memulai permainan, tombol exit untuk keluar dan tombol pengaturan sebagai menu yang berisi 3 tombol yaitu tombol informasi tentang pengembang game, tombol sound untuk pengaturan suara dan tombol music untuk pengaturan musik.

\section{Halaman Pilih Level}

Halaman pilih level memiliki 3 pilihan level yang akan dimainkan. Pada level 1 yaitu saat terjadi gempa bumi, level 2 mengumpulkan barangbarang dan level 3 menyelamatkan diri menuju tempat yang lebih aman. Halaman ini memiliki sistem lock level dimana ketika pemain telah menyelesaikan 1 level maka level selanjutnya akan terbuka. Terdapat tombol back untuk kembali ke halaman menu utama. Halaman pilih level dapat dilihat pada gambar 6 .

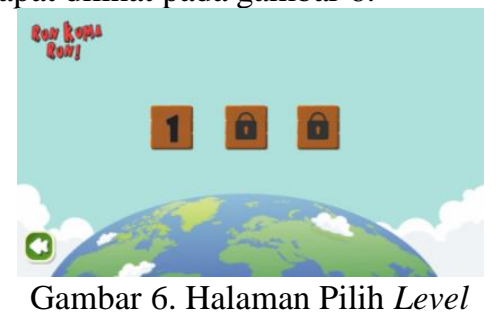

\section{Halaman Permainan}

Game ini memiliki 3 level dengan tingkat kesulitan dan tantangan yang berbeda-beda di setiap levelnya. Level 1, pemain menyelamatkan diri saat terjadi gempa bumi dengan menghindari batu-batu yang berjatuhan dan mencari 3 kunci untuk membuka pintu agar dapat keluar dari 
rumah. Level 2, pemain mengumpulkan perbekalan darurat saat terjadi gempa bumi dan menyelamatkan seekor kucing yang terjebak di dalam rumah. Level 3, pemain menyelamatkan diri menuju tempat evakuasi dan harus berhatihati terhadap pecahan kaca, papan reklame dan lampu jalan. pemain juga membantu seorang anak yang sedang terluka. Pemain dapat mengumpulkan koin disetiap level untuk mendapatkan poin. Halaman permainan dapat dilihat pada gambar 7-9.

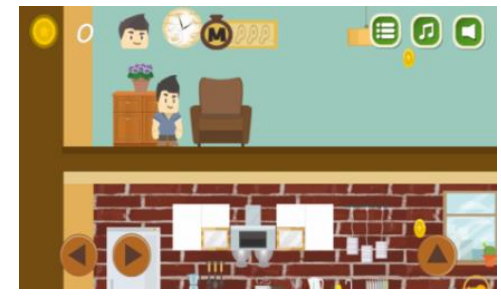

Gambar 7. Game Level 1

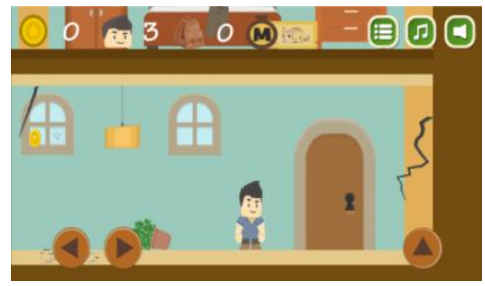

Gambar 8. Game Level 2

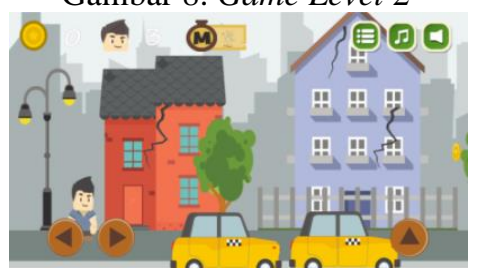

Gambar 9. Game Level 3

\section{Halaman Menang}

Jika pemain berhasil menyelesaikan misi dan tantangan di setiap level, maka akan muncul tampilan level complete yang berisi score dan informasi tentang gempa bumi. Terdapat tombol next untuk menuju ke level selanjutnya. Halaman menang dapat dilihat pada gambar 10 .

\section{Halaman Kalah}

Jika pemain gagal menyelesaikan misi dan tantangan, maka akan muncul tampilan game over. Terdapat tombol restart untuk mengulang permainan. Halaman kalah dapat dilihat pada gambar 11 .

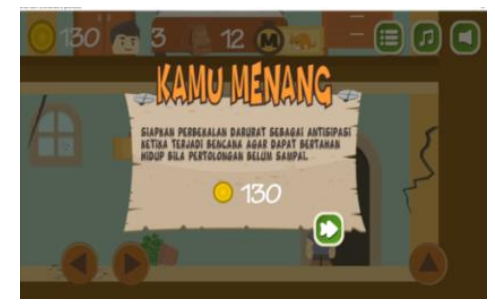

Gambar 10. Halaman Menang

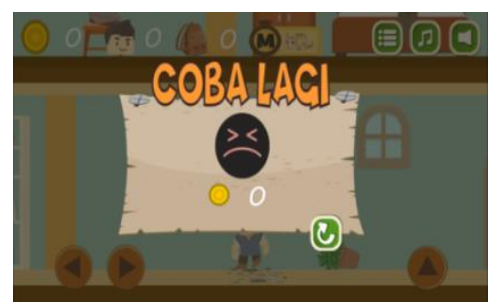

Gambar 11. Halaman Kalah

\section{Pembahasan Hasil Penelitian}

\section{Pengujian Black Box}

Pengujian black box adalah pengujian yang dilakukan dengan mengeksekusi data uji dan mengecek apakah fungsional data uji berjalan dengan baik [10]. Pengujian Black Box dapat dilihat pada tabel 3 .

Berdasarkan tabel 3 dapat disimpulkan bahwa semua tombol dan sistem pada game ini dapat berjalan dengan baik.

\section{Pengujian Usabilitas}

Pengujian Usabilitas dilakukan di MIM Kertonatan, pada tanggal 3 Mei 2019 dengan mendemokan game edukasi mitigasi gempa bumi di depan siswa-siswi kelas IV sampai VI.

Pengujian usabilitas menggunakan instrumen berupa kuisioner yang diisi setelah siswa selesai memainkan game dengan melibatkan 30 siswasiswi.

Berdasarkan hasil kuisioner yang telah diperoleh, perhitungan nilai dilakukan dengan menggunakan rumus SUS (System Usability Scale). Untuk perhitungan skor SUS dilakukan melalui beberapa aturan yaitu pernyataan dengan nomor ganjil $(1,3,5,7,9)$ maka rumusnya $x-1$ dimana $x$ adalah jawaban dari skala. Sedangkan pernyataan dengan nomor genap $(2,4,6,8,10)$ maka jawaban dari skala adalah $5-x$ dimana $\mathrm{x}$ adalah jawaban pada skala yang dipilih. Setelah itu menghitung total skor dikali 2,5. 
Tabel 3. Hasil Uji Black box

\begin{tabular}{|c|c|c|c|}
\hline \multicolumn{4}{|c|}{ Halaman Menu Utama } \\
\hline No & Yang Diuji & Hasil Yang Diharapkan & Hasil \\
\hline 1 & Tombol play & Masuk halaman pilih level & Tampil \\
\hline 2 & Tombol setting & $\begin{array}{l}\text { Muncul tombol information, } \\
\text { tombol sound dan tombol } \\
\text { music }\end{array}$ & Tampil \\
\hline 3 & $\begin{array}{l}\text { Tombol } \\
\text { information }\end{array}$ & Pop up tentang game tampil & Tampil \\
\hline 4 & Tombol sound & Sound berjalan / sound mati & Tampil \\
\hline 5 & Tombol music & Music berjalan / music mati & Tampil \\
\hline 6 & Tombol exit & $\begin{array}{l}\text { Pop up keluar tampil dan } \\
\text { aplikasi berhenti }\end{array}$ & Tampil \\
\hline \multicolumn{4}{|c|}{$\begin{array}{c}\text { Halaman Pilih Level } \\
\end{array}$} \\
\hline 7 & Tombol level 1 & $\begin{array}{l}\text { Masuk ke halaman game } \\
\text { level } 1\end{array}$ & Tampil \\
\hline 8 & Tombol level 2 & $\begin{array}{l}\text { Masuk ke halaman game } \\
\text { level } 2\end{array}$ & Tampil \\
\hline 9 & Tombol level 3 & $\begin{array}{l}\text { Masuk ke halaman game } \\
\text { level } 3\end{array}$ & Tampil \\
\hline 10 & Tombol back & $\begin{array}{l}\text { Kembali ke halaman menu } \\
\text { utama }\end{array}$ & Tampil \\
\hline \multicolumn{4}{|c|}{$\begin{array}{r}\text { Halaman Permainan } \\
\end{array}$} \\
\hline 11 & $\begin{array}{l}\text { Tombol touch } \\
\text { control }\end{array}$ & Player bergerak & Tampil \\
\hline 12 & Icon koin & Skor bertambah & Tampil \\
\hline 13 & Icon nyawa & Nyawa berkurang & Tampil \\
\hline 14 & Icon misi & Misi berhasil & Tampil \\
\hline 15 & $\begin{array}{ll}\text { Icon jumlah } \\
\text { barang }\end{array}$ & Jumlah barang bertambah & Tampil \\
\hline 16 & Tombol home & Kembali ke menu utama & Tampil \\
\hline 17 & $\begin{array}{l}\text { Tombol } \\
\text { music }\end{array}$ & Sound berjalan / sound mati & Tampil \\
\hline 18 & Tombol sound & Music berjalan / music mati & Tampil \\
\hline 19 & Icon koin & Skor bertambah & Tampil \\
\hline 20 & Icon nyawa & Nyawa berkurang & Tampil \\
\hline 21 & Icon misi & Misi berhasil & Tampil \\
\hline \multicolumn{4}{|c|}{ Halaman Menang } \\
\hline 22 & Tombol next & Masuk ke level selanjutnya & Tampil \\
\hline \multicolumn{4}{|c|}{ Halaman Kalah } \\
\hline 23 & Tombol restart & Mengulang permainan & Tampil \\
\hline
\end{tabular}

Berdasarkan hasil perhitungan SUS, diperoleh hasil pengujian di MIM Kertonatan pada siswa siswi kelas IV sampai VI dengan nilai rata-rata System Usability Scale (SUS) score yaitu 72,16. Rumus perhitungan nilai rata-rata menggunakan persamaan:

$$
\text { Nilai rata }- \text { rata }=\sum_{i=1}^{n} \frac{X i}{N}
$$

i : Nilai Skor Responden

$\mathrm{N}$ : Jumlah Responden

Maka:

Nilai rata-rata $=\frac{2165}{30}=72,16$
Tabel 5. Hasil Kuisioner dengan perhitungan SUS Keterangan Kode:

\begin{tabular}{|c|c|c|c|c|c|c|c|c|c|c|c|c|}
\hline \multirow[b]{2}{*}{$\begin{array}{l}\mathbf{N} \\
\mathbf{O}\end{array}$} & \multicolumn{10}{|c|}{ Butir Pertanyaan } & \multirow{2}{*}{$\begin{array}{c}\text { To } \\
\text { Ta } \\
1\end{array}$} & \multirow{2}{*}{$\begin{array}{c}\text { SUS } \\
\text { Sco } \\
r e \\
(\text { Tot } \\
\text { al } \\
* 2.5)\end{array}$} \\
\hline & $\begin{array}{l}\mathbf{P} \\
\mathbf{1}\end{array}$ & $\begin{array}{l}\mathbf{P} \\
2\end{array}$ & $\begin{array}{l}\mathbf{P} \\
\mathbf{3}\end{array}$ & $\begin{array}{l}P \\
4\end{array}$ & $\begin{array}{l}\mathbf{P} \\
5\end{array}$ & $\begin{array}{l}P \\
6\end{array}$ & $\begin{array}{l}\mathbf{P} \\
7\end{array}$ & $\begin{array}{l}P \\
8\end{array}$ & $\begin{array}{l}P \\
9\end{array}$ & $\begin{array}{c}P \\
10\end{array}$ & & \\
\hline 1 & 3 & 2 & 1 & 4 & 2 & 2 & 0 & 2 & 3 & 3 & 22 & 55 \\
\hline 2 & 3 & 3 & 3 & 1 & 4 & 3 & 3 & 3 & 3 & 0 & 26 & 65 \\
\hline 3 & 1 & 3 & 3 & 4 & 3 & 4 & 1 & 1 & 4 & 4 & 28 & 70 \\
\hline 4 & 4 & 1 & 1 & 0 & 4 & 0 & 3 & 3 & 4 & 0 & 20 & 50 \\
\hline 5 & 3 & 4 & 3 & 4 & 3 & 4 & 3 & 4 & 3 & 4 & 35 & 87,5 \\
\hline 6 & 3 & 4 & 4 & 4 & 3 & 3 & 4 & 4 & 3 & 3 & 35 & 87,5 \\
\hline 7 & 3 & 4 & 4 & 4 & 3 & 3 & 3 & 3 & 3 & 4 & 34 & 85 \\
\hline 8 & 3 & 4 & 4 & 3 & 3 & 3 & 3 & 3 & 4 & 2 & 32 & 80 \\
\hline 9 & 3 & 2 & 2 & 1 & 4 & 2 & 2 & 3 & 2 & 0 & 21 & 52,5 \\
\hline 10 & 3 & 2 & 2 & 1 & 3 & 2 & 2 & 3 & 2 & 0 & 20 & 50 \\
\hline 11 & 4 & 4 & 4 & 4 & 4 & 4 & 4 & 4 & 4 & 0 & 36 & 90 \\
\hline 12 & 3 & 3 & 3 & 3 & 3 & 4 & 4 & 4 & 4 & 4 & 35 & 87,5 \\
\hline 13 & 4 & 3 & 2 & 3 & 3 & 3 & 3 & 3 & 2 & 0 & 26 & 65 \\
\hline 14 & 4 & 3 & 3 & 3 & 3 & 3 & 3 & 3 & 3 & 3 & 31 & 77,5 \\
\hline 15 & 3 & 4 & 2 & 3 & 4 & 3 & 2 & 4 & 0 & 3 & 28 & 70 \\
\hline 16 & 1 & 3 & 3 & 4 & 4 & 3 & 4 & 4 & 3 & 3 & 32 & 80 \\
\hline 17 & 4 & 3 & 3 & 3 & 4 & 4 & 3 & 4 & 3 & 3 & 34 & 85 \\
\hline 18 & 3 & 3 & 3 & 3 & 3 & 4 & 4 & 4 & 4 & 4 & 35 & 87,5 \\
\hline 19 & 2 & 3 & 3 & 4 & 4 & 2 & 2 & 3 & 3 & 1 & 27 & 67,5 \\
\hline 20 & 1 & 3 & 3 & 3 & 3 & 3 & 3 & 3 & 3 & 1 & 26 & 65 \\
\hline 21 & 4 & 2 & 2 & 3 & 0 & 3 & 3 & 0 & 4 & 3 & 24 & 60 \\
\hline 22 & 4 & 4 & 4 & 4 & 4 & 4 & 4 & 4 & 4 & 0 & 36 & 90 \\
\hline 23 & 4 & 4 & 4 & 4 & 4 & 4 & 4 & 4 & 4 & 4 & 40 & 100 \\
\hline 24 & 4 & 2 & 4 & 3 & 4 & 3 & 1 & 3 & 1 & 1 & 26 & 65 \\
\hline 25 & 3 & 2 & 3 & 1 & 2 & 2 & 3 & 2 & 4 & 0 & 22 & 55 \\
\hline 26 & 3 & 2 & 2 & 1 & 3 & 3 & 1 & 4 & 3 & 0 & 22 & 55 \\
\hline 27 & 4 & 2 & 4 & 3 & 4 & 4 & 3 & 4 & 3 & 4 & 35 & 87,5 \\
\hline 28 & 3 & 2 & 2 & 3 & 3 & 3 & 3 & 3 & 3 & 3 & 28 & 70 \\
\hline 29 & 4 & 1 & 3 & 3 & 4 & 2 & 3 & 2 & 3 & 0 & 25 & 62,5 \\
\hline 30 & 4 & 1 & 4 & 1 & 4 & 2 & 4 & 3 & 2 & 0 & 25 & 62,5 \\
\hline
\end{tabular}

P1 : Menurut saya, saya menyukai aplikasi game ini sehingga akan memainkannya berkali-kali P2 : Menurut saya, game ini terlalu rumit untuk dimainkan

P3 : Menurut saya, game ini mudah digunakan P4: Saya membutuhkan bantuan orang lain untuk memainkan game ini (tidak dapat bermain sendiri tanpa dibantu)

P5 : Saya menganggap bagian-bagian game ini dapat dimainkan dengan baik

P6 : Menurut saya cara bermain dari game ini membingungkan

P7 : Menurut saya orang lain akan belajar bermain game ini dengan sangat cepat (mudah)

P8 : Saya menganggap game ini tidak praktis (sulit) dimainkan

P9 : Saya merasa bisa memainkan game ini

P10 : Saya perlu belajar banyak untuk dapat memainkan game ini

\section{Keterangan Nilai :}

1: Sangat tidak setuju

2 : Tidak setuju

3 : Ragu 
4 : Setuju

5 : Setuju sekali

Selanjutnya mengukur hasil rata-rata dengan

skala interval berikut:

$0-20$ : Sangat Buruk

21-40 : Buruk

$41-60:$ Cukup

$61-80$ : Baik

$81-100$ : Sangat Baik

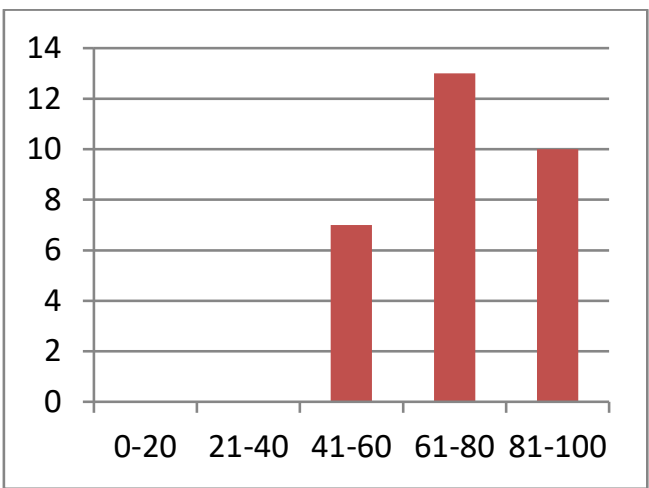

Gambar 12. Grafik perhitungan dengan rumus SUS

Berdasarkan hasil perhitungan nilai SUS dapat disimpulkan bahwa nilai rata-rata 72,16 berada diantara nilai $61-80$ yang berarti dapat berjalan dengan baik.

\section{KESIMPULAN DAN SARAN}

Berdasarkan uji black box aplikasi game ini, dapat disimpulkan bahwa aplikasi dapat berjalan baik pada perangkat mobile dengan operasi sistem android dalam ekstensi .apk. Sedangkan berdasarkan hasil kuisioner di MIM Kertonatan mendapat nilai rata-rata SUS Score 72,16. Adanya game ini, penulis berharap dapat memudahkan siswa siswi untuk menambah wawasan tentang mitigasi gempa bumi.

Beberapa saran untuk mengembangkan aplikasi game ini lebih lanjut yaitu :

1. Membuat kualitas dan resolusi gambar menjadi lebih baik lagi atau dikembangkan pada animasi 3D.

2. Menambah level dengan misi dan tantangan yang lebih bervariasi.

\section{UCAPAN TERIMAKASIH}

Puja dan puji syukur kepada Allah SWT yang telah melimpahkan rahmat dan hidayah-Nya dalam menyelesaikan tugas akhir ini. Peneliti mempersembahkan kepada kedua orang tua yang telah memberikan banyak dukungan baik secara moral maupun materil, Pembimbing saya ibu Endah Sudarmilah yang telah memberikan banyak bantuan dan motivasi dalam membimbing selama dua semester. Teman-teman seperjuangan yang tidak bisa saya sebutkan satu per satu dan pihak-pihak terkait.

\section{DAFTAR PUSTAKA}

[1] Malik, Y. (2009). Penentuan Tipologi Kawasan Rawan Gempabumi Untuk Mitigasi Bencana Di Kecamatan Pangalengan Kabupaten Bandung.

[2] Hidayati, D. (2008). Paradigma Baru Pengelolaan Bencana Alam Di Indonesia. Kependudukan Indonesia, III(I), 69-84.

[3] Teguh Martono, K. (2011). Perancangan Game Edukasi "Fish Identity" Dengan Menggunakan JavaTM. Jurnal Sistem Komputer, 1(1), 49-54.

[4] Jasson, Role Playing Game (RPG)Maker, Ari Pidekso, Yogyakarta: ANDI,2009, ISBN: 978-979-29-0839-8

[5] Tijan, F. R., Rianto, A. T., Afina, N., Yesmaya, V., Luwinda, A., Studi, P., \& Informasi, T. (2016). Perancangan Aplikasi Game " Fix Our Environment " Berbasis Android Game " Fix Our Environment " Applications Design. Jurnal Teknik Dan Ilmu Komputer, 19(5), 319-331.

[6] Sudarmilah, Endah., R. Ferdiana., L. E. Nugroho., A. Susanto. (2013). Teh review: Game platform for upgrading counting ability on Preschool Children. Prosiding on The 5th International Conference on Information Technology and Electrical Engineering.(1CITEE 2013).

[7] Bassil, Y. (2012). A Simulation Model for the Waterfall Software Development Life Cycle. 2(5). Retrieved from http://arxiv.org/abs/1205.6904.

[8] Fantechi, A., Gnesi, S., Lami, G., Maccari, A., Università, I., \& Area, I. C. N. R. (2001). Application of Linguistic Techniques for Use Case Analysis.

[9] Sulistyorini, P. (2009). Pemodelan Visual dengan Menggunakan UML dan Rational Rose. XIV(1), 23-29.

[10] Wibisono, W., \& Baskoro, F. (2002). Pengujian Perangkat Lunak Dengan Menggunakan Model Behaviour UML. Teknik Informatika Institut Teknologi Sepuluh Nopember Surabaya, 43-50. 